\title{
Analysis Of The Effect Of Perceptions On The Distribution Of Medical Services For Bpjs Patients And Organizational Climate On Job Satisfaction Of Doctors At Royal Prima Medan Hospital
}

\author{
Rini Elvira Hutabarat ${ }^{1}$, Adek Amansyah ${ }^{2 *}$, Ali Napiah Nasution ${ }^{3}$, Tan Suyono ${ }^{4}$ \\ 1,2,3,4 Universitas Prima Indonesia \\ *Corresponding Author: \\ Email: adekarmansyah@unprimdn.ac.id
}

\begin{abstract}
.
Job satisfaction among doctors is the main key to getting better health services. Changes in payment methods in the JKN era led to the dissatisfaction of specialists and general practitioners with the medical services received in BPJS patient care. This study analyzes the effect of perceptions about the distribution of medical services for BPJS patients on the job satisfaction of doctors. The research design used in this study was a descriptive analytic non-experimental study with a cross-sectional approach. The study was conducted at the Royal Prima General Hospital located in Medan City from May 2021 to August 2021. The sample in this study was selected using the purposive sampling method so that a sample of 77 people was obtained with the inclusion criteria of having worked for at least 2 years. Data were analyzed using the Chi-Square test and multiple logistic regression. The results showed that the total medical services received by general practitioners per month was 10 million rupiah. Meanwhile, the total number of medical visits and services received by specialist doctors per month is 25 million rupiah. Based on the results of the Chi-Square test, it can be seen that doctors' perceptions of medical services (number of medical services $(p=0.000)$, timeliness of delivery $(p=0.000)$, suitability of medical services with performance $(p=0.003)$, distribution system $(p=0.004)$, and transparency $(p=0.011))$ had a significant effect on doctor's job satisfaction. The results of multiple logistic regression test show that the variable with the greatest influence is the number of medical services. The variable number of medical services has a value of $\operatorname{Exp}(B)=29,830(95 \%$ CI 3,037-293,034) that means that respondents who state the number of good medical services are 29 times more likely to be satisfied than those who state that the number of medical services is less. Doctor's job satisfaction can be increased by the management's efforts to be more open to doctors regarding doctor's medical services, giving doctors the opportunity to improve their career paths, and conducting periodic evaluations of doctor's satisfaction through questionnaires.
\end{abstract}

Keywords: Medical incentives, job satisfaction, doctors

\section{INTRODUCTION}

The health sector is a labor-intensive sector where the quality of patient care services is directly related to workers' satisfaction with their work, motivation and readiness to apply resources to tasks in the workplace. Job satisfaction among doctors is a very important issue in the present context where doctors had great autonomy in the past (Bhattacherjee et al., 2016). The doctor's model of working and the way health 
care is provided has changed greatly over the past few decades. Factors such as health information obtained from the internet, frequent malpractice demands, reduced patient relations, and time pressures associated with managed care have affected physician job satisfaction (Ha \& Longnecker, 2010). Job satisfaction among doctors is the main key to getting better health services (Atif et al., 2015).Dissatisfaction with doctors' work is often experienced in developing countries due to the high workload. Working long hours and overtime has been shown to be associated with job dissatisfaction (Oman et al., 2009: Sheikh et al., 2012). Various studies have identified the determinants of a doctor's job, career, and professional satisfaction. Research has shown that physician satisfaction can be influenced by personal and contextual factors, as well as by intrinsic characteristics of the medical profession.

Personal factors include age, years of practice, gender, professional achievement, personal satisfaction, nationality, race, and ethnicity. Contextual factors refer to people in the work environment, including work autonomy and control, workload, job demands, co-worker relationships, perceived quality of care, payment and contractual arrangements, academic and administrative duties, income, financial and non-financial incentives. , leadership, relationship with support staff, use of electronic medical records, and implementation of health care reform. Intrinsic factors refer to the inherent characteristics of the medical profession, such as patient interactions, demographics and complexity, as well as their own specialization (PeñaSánchez et al., 2013: Friedberg et al., 2014: Hoff et al., 2015).Incentives have been identified as the organizational factor that has the strongest correlation with job satisfaction. Fair, reasonable, and equal wages increase job satisfaction (Al-Zoubi, 2012: Young et al., 2014). A study conducted by Eltarhuni \& Alaqeli (2019) shows that salary ranks first as important to encourage doctor's performance, while stability in work ranks second, the last is good relations with superiors and coworkers.

There is a positive relationship between incentives and performance and a significant relationship is determined between incentives (financial and moral) and personal variables such as performance and gender. Research in various countries also shows that income and workload balance are related to physician job satisfaction (Jaiswal et al., 2015).Doctors in America have the highest salaries of any other country in the world. The average salary for general practitioners alone reaches 186,044 dollars, or around Rp. 2.2 billion (exchange rate: Rp. 12 thousand) per year, while the salary for specialists is 339,738 dollars, or around Rp. 4.1 billion per year. This total salary can also be higher if doctors practice in private hospitals. In the UK, the average salary of a family doctor is 75,500-pound sterling, or around Rp 1.4 billion per year, which is interesting, besides the average hourly salary, salary is also calculated based on age. The older a doctor, for example, 40-50 years, the wages can reach IDR 1 trillion (Sadeli et al., 2018). Prior to the implementation of the National Health Insurance (JKN) system through the Health Insurance Administration Agency (BPJS) in Indonesia in 
2013, the take home pay of specialist doctors who became civil servants and practiced in government hospitals referred to the staffing regulations set by the government. For example, a doctor with class IV, with a working period of more than 20 years, the average basic salary is around Rp. 4-5 million.

If you add a fixed incentive of Rp. 1.5 million and patient visit services, the average take home pay is around Rp. 10 million. This is for specialists who do not require medical skills, such as internal medicine specialists or dermatologists. As for specialist doctors who need medical skills, such as cardiac surgeons, the take home pay can reach Rp. 20 million. But the amount received is not comparable to the income of specialist doctors in private hospitals which can reach 50 million rupiah (Lubis, 2013). One method of paying, namely fee for service (FFS), has so far been considered the cause of increased health costs, so that in many countries the FFS method is starting to be abandoned and replaced by new methods such as pay for performance (PFP) (Heryana, 2021). The National Health Insurance System (JKN) has fundamentally changed the model and payment mechanism for health facilities. Doctors, clinics, and hospitals are no longer paid in cash directly by patients, but are paid prospectively by the Health Social Security Administration Agency (BPJS). The amount of the fee is determined by means of the Indonesia Case Based Group (INA-CBG's). In the INACBG's system, the rates are according to the diagnosis of the disease and the type of hospital. So, the higher the type of hospital, the higher the rate issued in accordance with the diagnosis of the disease. Doctors pay using a remuneration system (doctors' salaries are based on performance). This rate is similar to a monthly salary and is received in a fixed amount. The remuneration system is an agreement between doctors and hospital management as well as the government. The remuneration rate is paid at the package price in INA-CBG's, including the use of drugs and other facilities (BPJS Kesehatan, 2014 ).Doctors as professionals greatly affect services in hospitals.

Usually these professionals tend to be autonomous and independent, and sometimes their mission is not in line with hospital management (Aditama, 2002). The INA-CBGs system has a philosophy of transferring risk to a health facility where the doctor also bears the risk of costs if he provides services that are not in accordance with established procedures. This will encourage changes in behavior and the way doctors practice medicine (BPJS Kesehatan, 2014). Based on the average acceptance of medical services from doctors at RSU Royal Prima Medan, it can be seen that orthopedic specialists are the doctors with the highest acceptance of medical services, while the lowest is the medical services of skin and genital health specialists. The difference in medical services is influenced by the achievements of doctors in dealing with the number of patients and the medical actions performed on patients. This condition causes the dissatisfaction of specialists and general practitioners to the medical services received in BPJS patient care. As a result, it has an impact on the credibility of doctors and the maximum of doctor services. It can be seen from hospital data, that the number 
of general practitioners in 2020 is 24 people and specialist doctors are 58 people, while in 2021 the number of doctors has decreased, namely general doctors as many as 20 people and specialist doctors as many as 48 people.

The decrease in the number of general practitioners and specialists is assumed to be due to the dissatisfaction of doctors so that many doctors resign.Doctor's dissatisfaction can be seen from the results of the doctor's performance assessment by the hospital medical committee team which is carried out every four months, where from the data from the credentialing section of the hospital medical committee team, it can be seen the results of the medical committee team's assessment in May 2021 the doctor's performance in terms of doctor attendance for visits is 80 percent, while the results of the assessment in December 2020 have decreased to 76.3 percent. In terms of the punctuality of doctors coming to practice in the outpatient unit, the results of the August 2020 assessment were 79.5 percent. Whereas in December 2020 it decreased to 76.3 percent. In terms of receiving complaints from patients or their families, the results of the August 2020 assessment were 19.2 percent while in December 2020 it increased to 23.4 percent. This decline in the performance of doctors is assumed to be the result of physician dissatisfaction. Based on the results of interviews during the initial survey conducted by researchers on four general practitioners and four specialist doctors at RSU Royal Prima Medan, information was obtained that specialist doctors answered that they were not satisfied with the number of medical services provided by the hospital and were not satisfied with the timeliness of service delivery. medical treatment, this can be seen from the performance appraisal of specialists who have decreased. The specialist is often late in coming to the hospital, not in accordance with the opening time of the outpatient polyclinic that was notified to the patient.

\section{LITERATURE REVIEW}

\subsection{Job Satisfaction}

According to Davis (1985) quoted in Mangkunegara (2016) revealed that "job satisfaction is the favorableness or unfavorableness with employees view their work". (Job satisfaction is a supportive or unsupportive feeling experienced by employees at work). Wexley and Yuki (1977) in Mangkunegara (2016) define job satisfaction as "is the way an employee feels about his or her job". (It is the way employees feel about themselves or their work). Based on the opinion of Davis, Wexley, and Yuki mentioned above, job satisfaction is a feeling that supports or does not support employees who are related to their work or their condition. Feelings related to work involve aspects such as wages or salaries received, career development opportunities, relationships with other employees, job placement, type of work, company organizational structure, quality of supervision, while feelings related to themselves include age, condition health, skills, education. Employees will feel satisfied at work if aspects of the work and aspects of 
themselves support and vice versa if these aspects do not support, employees will feel dissatisfied.

There are two factors that affect job satisfaction, namely (Mangkunegara, 2018):

1. Employee factors, namely intelligence (IQ), special skills, age, gender, physical condition, education, work experience, years of service, personality, emotions, ways of thinking, perceptions, and work attitudes.

2. Occupational factors, namely type of work, organizational structure, rank (class), position, quality of supervision, financial security, opportunity for promotion, social interaction, and work relations.

\subsection{Perseption}

Sugihartono et al. (2007) suggested that perception is the brain's ability to translate stimuli or processes to translate incoming stimuli into the human senses. In human perception there are different points of view in sensing. There are those who perceive something as good or positive or negative perceptions that will affect visible or real human actions. Walgito (2004) revealed that perception is a process of organizing, interpreting the stimulus received by the organism or individual so that it becomes something meaningful, and is an integrated activity within the individual. Responses as a result of perception can be taken by individuals in various forms. Which stimulus will get a response from the individual depends on the attention of the individual concerned. Based on this, feelings, thinking abilities, experiences that individuals have are not the same, so in perceiving a stimulus, the perception results may differ from one individual to another.

Everyone has a tendency to see the same thing in different ways. These differences can be influenced by many factors, including knowledge, experience and point of view. Perception is also related to one's perspective on a certain object in different ways by using the senses they have, then trying to interpret it. Perceptions, both positive and negative, are like data that has been stored neatly in our subconscious mind. The data will appear immediately when there is a stimulus that triggers it, there is an event that opens it. Perception is the result of the brain's work in understanding or assessing something that is happening around it (Waidi, 2006). Jalaludin (2007) states that perception is an observation about objects, events or relationships obtained by inferring information and interpreting messages. Suharman (2005) states: "perception is a process of interpreting or interpreting information obtained through the system of human senses". According to him, there are three aspects in perception that are considered relevant to human cognition, namely sense recording, pattern recognition, and attention.

\subsection{Service}

Kotler \& Keller (2009) say that service is any action or performance offered by one party to another that is essentially intangible and does not result in a transfer of ownership. The production of services may or may not be tied to a physical product. 
According to Stanton (2003) "Service is an activity that can be identified separately, which is essentially intangible, which is the fulfillment of needs, and does not have to be tied to the sale of other products or services. To produce services, it may or may not be necessary to use tangible objects. However, even if the use of the object is necessary, there is no transfer of ownership of the object (permanent ownership). According to Hamdani (2006), basically services are all economic activities whose results are not in the form of physical products or construction, which are generally produced and consumed simultaneously and provide added value to consumers.

Services have several main characteristics that distinguish them from goods. According to Koller (2010) the characteristics of these services are:

\section{Intangibility}

Services are intangible, meaning they cannot be seen, tasted, touched, or smelled before they are purchased. This results in customers not being able to predict the results before buying the service. The difficulty of predicting a service makes someone look for evidence that can show the quality of a service. The quality of a service can be predicted through the place where the service is produced or produced by the person producing the service, equipment, communication tools, symbols and the price of the service.

2. Inseparability

In contrast to the case with physical goods that are produced, stored in inventory, distributed through various sellers and when services are produced and directly consume these services. This results in the quality of service being determined by the interaction of the producer with the customer. Therefore, individual effectiveness in delivering services is an important element in service delivery.

3. Variability

Services vary widely because they depend on who produces them, when and where they are produced. Service buyers are aware of the high variability of services and usually seek information or discuss it with others before purchasing a service. There are three factors that cause service variability, namely cooperation/customer participation during service delivery, employee morale or motivation in serving customers and company workload.

4. Perishability

Services are non-durable commodities and cannot be stored. Thus, if a service is not used, then the service will pass away. This makes production capacity a critical factor. Perishability also affects the management of demand for services. If the demand is constant, the company will not face complicated problems. But if demand fluctuates, the company will face complicated problems, so companies need to make adjustments between production capacity or supply and demand. 


\subsection{Remuneration}

Remuneration is a term that is often associated with the world of employment, especially in the context of the wage or salary system. However, in its development, this term is also often used contextually, so it has a variety of meanings. In the context of the government bureaucracy, remuneration is associated with restructuring the employee payroll system based on performance appraisals, with the aim of creating a good and clean government governance system. Meanwhile, in the context of the company, remuneration is defined as a form of remuneration or reward received by employees for their performance. In the Regulation of the Minister of Finance of the Republic of Indonesia Number 10 of 2006 concerning Guidelines for Determining Remuneration for Management Officials, Supervisory Boards and Employees of Public Service Agencies, remuneration is an employee benefit which can be in the form of salary, honorarium, fixed allowances, incentives, bonuses for achievements, severance pay, and or pensions.

The Indonesian Ministry of Health through its Decree No. 625/Menkes/SK/V/2010 concerning Guidelines for Formulating a Remuneration System for Hospital BLU Employees explains the concept of remuneration consisting of 3Ps, namely:

\section{Pay for position}

This concept is based on a person's position or title (structural, functional, staff), responsibility and level of risk. Pay for position in the form of allowances.

\section{Pay for people}

This concept is based on rank and class, years of service, education/profession/competence. Pay for people in the form of basic salary.

\section{Pay for performance}

This concept is based on the achievements of the workers. Pay for performance can be in the form of incentives and bonuses.

\section{METHODOLOGY}

The research design used in this study is a descriptive analytic nonexperimental study with a cross sectional approach, which is a type of research that emphasizes the measurement/observation time of independent and dependent variable data only once at a time. This study aims to determine the effect of perceptions about the distribution of medical services (independent variable) from BPJS patient services on doctor satisfaction (dependent variable) at the Royal Prima General Hospital Medan. The population in this study were all doctors at the Royal Prima General Hospital Medan as many as 111 people (consisting of 30 general practitioners and 81 specialists). The sample in this study was selected using purposive sampling method. Purposive sampling is a sampling technique with certain considerations according to research needs. Inclusion criteria in determining the sample are doctors and specialists 
who have worked at least 2 years Royal Prima General Hospita Medan. After carrying out the research that meets the requirements to be a sample, there are 77 people.

\section{DISCUSSION}

\subsection{The Influence of the Number of Medical Services on Doctor's Job Satisfaction}

The respondent's perception of the number of medical services received is calculated from the number of times the respondent visits the patient and every action taken by the respondent. The results of the Chi-Square test show that the variable number of medical services has a significant effect on doctor's job satisfaction. This is in accordance with what was said by Gibson (21005), namely that the reward is the amount of wages received and considered a reasonable wage by employees, basically someone who works expects rewards that are in accordance with the type of work. The existence of incentives that are in accordance with the work, it will also arise a sense of work passion that is getting better. The rewards of work take many forms and do not always depend on money. Rewards are things that encourage the workforce to work harder, the salary/intensive factor affects the job satisfaction of the respondents (Sejati et al., 2016).

The results of the study based on the results of interviews with respondents showed that some doctors said the number of medical services received was in accordance with the amount perceived by the respondents, the number of medical services now received by respondents was in accordance with the calculations agreed upon from the start and the management informed the respondents about how to calculate the services. medical treatment, this affects the job satisfaction of the respondents and they feel satisfied that they can serve patients as much as possible.

Research conducted by Laura (2017) shows that the number of medical services received is quite good and medical services affect job satisfaction because there are appropriate rewards received by workers for the work itself so that it can increase motivation at work. The study of Nafi'ah et al. (2016) concluded that there is a relationship between perceptions of the number of medical services and job satisfaction where job satisfaction is obtained from the level of rewards or results obtained from work, compared to what employees expect or value.

\subsection{The Effect of Timeliness of Giving on Doctor's Job Satisfaction}

The timeliness of receiving medical services is the time the respondent receives medical services from the hospital where the respondent's perception of the timeliness of receiving medical services is at the beginning of each month until the middle of the month. The results of the logistic regression test showed that the punctuality variable did not have a significant effect on doctor's job satisfaction. Based on the results of interviews with respondents, it shows that some respondents said that respondents were used to the inaccuracy of receiving medical services and medical services were not 
received regularly every month by respondents because it was related to the BPJS payment system which was experiencing delays and the possibility of frequent policy changes. Respondents also said that the management did not inform in advance if there was a delay in receiving medical services but the respondents were used to it so this did not affect the respondent's job satisfaction in the hospital. Respondents said that being late in receiving medical services is not a problem as long as medical services will still be received and salaries are still received every month. In this case the management can approach the determining parties so that medical services can be received on time, and can be transparent in the calculation of medical services received by doctors so that all parties can receive and understand well.Herawati (2006) and Djafar (2012) research shows that there is a relationship between the timeliness of receiving medical services and doctor's job satisfaction, where doctors will feel satisfied if medical services are received on time and routinely. Rosmita's research (2012) shows that the consistency factor in the distribution of medical services has an effect on job satisfaction.

\subsection{Effect of Suitability of Medical Services with Performance on Doctor's Job Satisfaction}

Respondents' perception of the suitability of medical services with performance is that the calculation of medical services is carried out based on the type of action that the respondent does and the amount of action taken. The results of the logistic regression test showed that the medical service suitability variable did not have a significant effect on the job satisfaction of doctors at Royal Prima Hospital Medan. Robbins \& Judge (2014) argue that if wages are given fairly according to job demands, individual skill levels and community wage standards, it is likely to result in worker satisfaction. The results of the study indicate that the discrepancy between medical services and performance is indicated by, among others, respondents' statements as follows:

1. The medical services received are not in accordance with the workload

2. The amount of medical services is not commensurate with the risk of the job

3. Medical services received are not as expected

4. The difference in the number of medical services received is not based on an objective assessment

The results of the study based on the results of interviews with respondents showed that the above did not affect the respondent's job satisfaction in the hospital because according to the respondent, so far the hospital had never limited the actions taken and to be carried out by the respondent to the patient. Almost all the procedures performed by the respondent were approved by the hospital so that the respondent still felt comfortable and satisfied working in the hospital.The results of this study are also not in line with Laura's research (2017) which states that there is a relationship between the suitability of medical services and performance on the job satisfaction of doctors and with incentives that are appropriate to their work, there will also be a better sense 
of work passion. Judge (1980) also stated that salary has a positive effect on job satisfaction. Basically, someone who works expects a reward that is in accordance with the type of work. Because there are rewards that are in accordance with the work, there will also be a better sense of work passion, the rewards of work take various forms, not always depending on money.

\subsection{The Effect of Distribution System on Doctor's Job Satisfaction}

The distribution system of medical services according to respondents' perceptions is a way for hospitals to distribute the amount of medical services based on what the respondents have done. The results of the logistic regression test showed that the medical service distribution system variable had a significant effect on doctor's job satisfaction. Based on the results of the interviews, it was shown that some doctors said that there were things that were not known about the medical service distribution system, namely the transparency of the distribution of medical services, meaning that the hospital had not fully provided clear information to all respondents regarding how to distribute and calculate the medical services that would be received by them. respondents to each of these respondents. Respondents still do not understand how the distribution of medical services carried out by the hospital so that there is often a difference between the number of medical services received by the respondent and that calculated by the respondent himself.

Respondents said that the distribution system carried out by the hospital is currently not commensurate with the amount of work and the responsibilities and risks that respondents face from the work carried out by respondents. Respondents hope that the management will reassess the work that respondents do to determine how the system of distributing medical services is fair to respondents. Respondents also said that they felt that the current medical service distribution system was different from the distribution system that was notified to respondents when the respondent first entered the hospital and there was no notification from the hospital regarding any changes from the medical service distribution system to respondents from the hospital. Respondents said that they had high hopes that the hospital would inform them of the distribution system of medical services in the hospital. The results of this study are in line with research conducted by Rosmita (2012) and Nafiah (2016) that the medical service distribution system is the dominant factor influencing job satisfaction.

\subsection{The Effect of Transparency on Doctor's Job Satisfaction}

Transparency of medical services according to the respondent's perception is that the hospital announces the calculation of medical services every month openly to the respondent and if there is a change in the calculation of medical services, the hospital notifies the respondent about the change. The results of the logistic regression test showed that the transparency variable had no significant effect on physician job satisfaction. A study conducted by Nurhayani (2006) concluded that specialist doctors strongly disagree with the amount of medical services received in accordance with the 
work done. Transparency in the provision of medical services can also indirectly affect job satisfaction. A specialist doctor who knows the results of his efforts clearly and in detail will judge that the hospital management appreciates his work (Laura, 2017). In the research of Tjung et al. (2012) in a private hospital, namely Eka Hospital BSD-City regarding the attachment of specialist doctors, the hospital management created a system called Guaranteed Income. In this system, a compensation is a guarantee of income for doctors with the aim of binding specialist doctors not to work elsewhere to seek additional income. The amount of the guarantee is determined by a remuneration system according to hospital policy. The remuneration system is set based on partnerships, skills, experience and number of patients, aiming to make specialist doctors feel more comfortable and focus on providing services to Eka Hospital patients. The results of this study obtained balanced results regarding the perception of specialist doctors on remuneration, namely assessing good and half assessing less well.

The assessment of the provision of medical services is subjective, meaning that no human being is ever very satisfied in terms of income or income. The results of the study based on interviews with respondents showed that some doctors said that the hospital was not transparent in terms of the details of the calculation of medical services and the hospital did not notify the respondent if there was a change in the calculation of the medical services that the doctor would receive. This does not affect the job satisfaction of doctors because some doctors only work to seek their own satisfaction in serving patients. As functional staff, respondents will be more satisfied if there is clarity on the medical services they receive every month so as not to arouse suspicion from each other, namely regarding the accuracy of receipts, routines, there is an explanation of how many percent are received as medical services and there is a prior agreement so that both parties between management as managers and respondents as functional staff become more understanding of a policy and are transparent and can cross check each other, this will certainly encourage functional staff to work more enthusiastically so that job satisfaction increases.

\section{CONCLUSSION AND RECOMMENDATION}

Based on the results of the research and discussion that have been described previously, the following conclusions can be drawn:

1. The total number of medical services received by general practitioners per month is 10 million rupiah. Meanwhile, the total number of medical visits and medical services received by specialist doctors per month is 25 million rupiah.

2. The number of medical services has a significant effect on job satisfaction, where the statistical test results show the $\mathrm{p}$ value is less than 0.05

3. Punctuality has a significant effect on job satisfaction, where the results of statistical tests show the $\mathrm{p}$ value is less than 0.05 
4. The number of medical services has a significant effect on job satisfaction, where the results of statistical tests show the $\mathrm{p}$ value is less than 0.05

5. The suitability of medical services has a significant effect on job satisfaction, where the statistical test results show the $\mathrm{p}$ value is less than 0.05

6. The distribution system has a significant effect on job satisfaction, where the results of statistical tests show the $\mathrm{p}$ value is less than 0.05

7. The results of the multiple logistic regression test show that the variable with the greatest influence is the number of medical services. The variable number of medical services has a value of $\operatorname{Exp}(B)=29,830$ (95\% CI 3,037-293,034) which means that respondents who state the number of good medical services are 29 times more likely to be satisfied than those who state that the number of medical services is less.

\subsection{Recommendation}

1. Increase doctor job satisfaction through increasing promotion opportunities by considering the doctor's ability both in terms of knowledge or skills that doctors have acquired through ongoing training or by providing doctors with opportunities to improve knowledge and skills in order to get opportunities for promotion.

2. The distribution system of medical services must be carried out fairly and openly, because the current distribution system is felt by the respondents to be unclear and the respondents still do not understand how the actual distribution system is.

3. Evaluate the job satisfaction of doctors on a regular basis with a questionnaire.

4. Communicating effectively with all doctors on a regular basis to determine the doctor's perception of the hospital in terms of infrastructure and comfort.

5. The hospital must reach an agreement with the doctors about the arrangement of payment of services (medical services) / remuneration that satisfies all parties including doctors, other staff and hospital management.

\section{REFERENCES}

[1] Aditama, T., 2002. Manajemen Administrasi Rumah Sakit. UI Press, Jakarta.

[2] Al-Assaf, A.F., 2009. Mutu Pelayanan Kesehatan Perspekstif Internasional. EGC, Jakarta.

[3] Al-Zoubi, M., 2012. The Shape of the Relationship between Salary and Job Satisfaction: A Field Study. Far East J. Psychol. Bus. 7 No 3 Pap, 1-12.

[4] Atif, K., Khan, H.U., Maqbool, S., 2015. Job satisfaction among doctors, a multi- faceted subject studied at a tertiary care hospital in Lahore. Pakistan J. Med. Sci. 31, 610-614. https://doi.org/10.12669/pjms.313.7402

[5] Bhattacherjee, S., Ray, K., Roy, J.K., Mukherjee, A., Roy, H., Datta, S., 2016. Job satisfaction among doctors of a tertiary care hospital of eastern India. Nepal $\mathbf{J}$. Epidemiol. 6, 595-602. https://doi.org/10.3126/nje.v6i3.14762

[6] BPJS Kesehatan, 2014. Panduan Praktis Sistem Rujukan Berjenjang. Sagung Seto, Jakarta. 
[7] Curphy, H.G., 2012. Leadership. Salemba Humanika, Jakarta.

[8] Djafar, 2012. Faktor Insentif, Kepemimpinan, Kondisi Lingkungan Kerja dan Kesempatan Promosi Yang Berpengaruh Terhadap Kepuasan Kerja Dokter Spesialis di RSUP Dr. Wahidin Sudirohuso. Universitas Hasanuddin.

[9] Eltarhuni, A., Alaqeli, E., 2019. Impact of Incentives on Physicians' Performance at Pediatric Hospital in Benghazi. IOSR J. Nurs. Heal. Sci. 6, 32-35. https://doi.org/10.9790/1959-0604053235

[10] Friedberg, M.W., Chen, P.G., Van Busum, K.R., Aunon, F., Pham, C., Caloyeras, J., Mattke, S., Pitchforth, E., Quigley, D.D., Brook, R.H., Crosson, F.J., Tutty, M., 2014. Factors Affecting Physician Professional Satisfaction and Their Implications for Patient Care, Health Systems, and Health Policy. Rand Heal. Q. 3, 1.

[11] Gibson, R., 2005. Principles of Nutrional Assesment. Oxford University, New York.

[12] Ha, J.F., Longnecker, N., 2010. Doctor-patient communication: a review. Ochsner J. $10,38-43$.

[13] Herawati, 2006. Analisis Faktor-Faktor Manajemen Yang Berpengaruh Terhadap Kepuasan Kerja Dokter di RSUD Kota Semarang. Universitas Diponegoro.

[14] Heryana, A., 2021. Asuransi Kesehatan dan Managed Care: Buku Ajar.Universitas Esa Unggul, Jakarta.

[15] Hoff, T., Young, G., Xiang, E., Raver, E., 2015. Understanding U.S. Physician Satisfaction: State of the Evidence and Future Directions. J. Healthc. Manag. 60, 409427.

[16] Ilyas, Y., 2012. Kinerja, Teori, Penilaian Dan Penelitian. Pusat Kajian Ekonomi Kesehatan FKM Universitas Indonesia, Jakarta.

[17] Jaiswal, P., Gadpayle, A.K., Singhal, A.K., Sachdeva, S., Modi, R.K., Padaria, R., Ravi, V., 2015. Job satisfaction among hospital staff working in a Government teaching hospital of India. Med. J. Dr. D.Y. Patil Univ. 8, 131- 137. https://doi.org/10.4103/0975-2870.153136

[18] Jalaludin, R., 2007. Persepsi Dalam Proses Belajar Mengajar. Rajawali Pers, Jakarta.

[19] Kotler, P., Keller, K.L., 2012. Manajemen Pemasaran, 14th ed. Erlangga, Jakarta.

[20] Laura, 2017. Faktor-Faktor Yang Berhubungan Dengan Kepuasan Kerja Dokter Spesialis di Instalasi Rawat Jalan RSUP Prof. Dr. R. D. Kandou Manado. Universitas Sam Ratulangi.

[21] Mangkunegara, A.A.A.P., 2016. Manajemen Sumber Daya Manusia Perusahaan. Remaja Rosdakarya, Bandung.

[22] Moekijat, 2009. Administrasi Gaji dan Upah. Bandar Maju, Bandung.

[23] Nafi'ah, A.C., Suryawati, C., Fatmasari, E.Y., 2016. Faktor Yang Berhubungan Dengan Kepuasan Kerja Dokter Spesialis Rumah Sakit Islam Sultan Agung Semarang Pasca Implementasi Jaminan Kesehatan Nasional. J. Kesehatan. Masy. 4, 1-11.

[24] Nurhayani, S., 2006. Beberapa Faktor Yang Berhubungan Dengan Kepuasan Kerja Dokter Spesialis di Poliklinik Rawat Jalan RSU Dr. Kanujoso Djatiw Ibowo Kota Balikpapan. Universitas Diponegoro.

[25] Oman, K.M., Moulds, R., Usher, K., 2009. Professional satisfaction and dissatisfaction among Fiji specialist trainees: what are the implications for preventing migration? Qual. Health Res. 19, 1246-1258. https://doi.org/10.1177/1049732309344116 
[26] Peña-Sánchez, J.N., Lepnurm, R., Bermedo-Carrasco, S., 2013. Latent gender inequalities in the well-being of physicians according to payment method for practicing medicine: a cross-sectional study. J. Hosp. Adm.

2, 7. https://doi.org/10.5430/jha.v2n4p7

[27] Robbins, S.P., 2007. Perilaku Organisasi, Konsep, Kontroversi, Aplikasi. PT Pranhelindo, Jakarta.

[28] Robbins, S.P., Judge, T.A., 2014. Perilaku Organisasi. Salemba Empat, Jakarta. Robbins, Stephen P., Judge, T.A., 2014. Perilaku Organisasi. Salemba Empat,Jakarta.

[29] Rosmita, N., 2012. Pengaruh Sistem Pembagian Jasa Medik Terhadap Kepuasan Kerja Perawat Pelaksana di RSUD Dr. H. Yuliddin Away Tapaktuan. Universitas Sumatera Utara.

[30] Sadeli, L., Yustina, I., Aulia, D., 2018. The Effect of Incentives on Satisfaction of Specialists at Imelda General Hospital, Medan, North Sumatera, in: The 4th International Conference on Public Health 2018. p. 269. https://doi.org/10.26911/theicph.2018.04.37

[31] Sejati, D.H., Komariah, A., Abubakar, 2016. Pengaruh Insentif Terhadap Disiplin Kerja Pegawai Negeri Sipil Di PPPPTK TK Dan PLB Bandung. Adpend 91- 101.

[32] Sheikh, A., Naqvi, S.H.A., Sheikh, K., Naqvi, S.H.S., Bandukda, M.Y., 2012. Causes of physician migration. Global. Health 51, 305-10. https://doi.org/10.1097/00001888197604000-00005

[33] Siswanto, B., 2013. Manajemen Tenaga Kerja Indonesia: Pendekatan Administratif dan Operasional. Bumi Aksara, Jakarta.

[34] Stanton, W.J., 2003. Prinsip Pemasaran, 7th ed. Erlangga, Jakarta.

[35] Sugihartono,Harahap,F.,Setiawati,F.,NurhayatiS., 2007.Psikologi Pendidikan. UNY Press, Yogyakarta.

[36] Suharman, M.S., 2005. Psikologi Kognitif. Srikandi, Surabaya.Group, Jakarta.

[37] Tjung, L., Meliala, A., Trisnantoro, L., 2012. Keterlekatan Dokter Spesialis di EKA Hospital BSD-City dan Pekanbaru. J. Manaj. Pelayanan Kesehat. 15, 115-123.

[38] Waidi, 2006. Pemahaman dan Teori Persepsi. Remaja Karya, Bandung. Walgito, B., 2004. Psikologi. Andi Offset, Yogyakarta.

[39] Young, L., Milner, M., Edmunds, D., Pentsil, G., Broman, M., 2014. The tenuous 